\title{
Resistin-induced cardiomyocyte hypertrophy is inhibited by apelin through the inactivation of extracellular signal-regulated kinase signaling pathway in $\mathrm{H9c2}$ embryonic rat cardiomyocytes
}

\author{
JIAN-WEI LUO ${ }^{1}$, XIAN ZHENG ${ }^{1}$, GUAN-CHANG CHENG ${ }^{2}$, QUN-HUI YE ${ }^{2}$, YONG-ZHI DENG ${ }^{1}$ and LIN WU $^{2}$ \\ ${ }^{1}$ Department of Cardiovascular Surgery, The Affiliated Cardiovascular Hospital of Shanxi Medical \\ University, Shanxi Cardiovascular Hospital (Institute), Taiyuan, Shanxi 030024; ${ }^{2}$ Department of \\ Cardiology, Huaihe Hospital of Henan University, Kaifeng, Henan 475000, P.R. China
}

Received May 23, 2016; Accepted August 18, 2016

DOI: $10.3892 /$ br.2016.749

\begin{abstract}
It has been reported that resistin induces, whereas apelin inhibits cardiac hypertrophy. However, the underlying molecular mechanisms of apelin inhibiting resistin-induced cardiac hypertrophy remain unclear. The aim of the current study is to investigate the effects of apelin on resistin-induced cardiomyocyte hypertrophy and elucidate the underlying molecular mechanism. H9c2 cells were used in the present study, and cell surface area and protein synthesis were evaluated. Reverse transcription-quantitative polymerase chain reaction was performed to analyze the expression levels of hypertrophic markers, brain natriuretic peptide (BNP) and $\beta$-myosin heavy chain ( $\beta$-MHC). In addition, western blotting was conducted to examine phosphorylation of extracellular signal-regulated kinase (ERK)1/2. Following treatment of $\mathrm{H} 9 \mathrm{c} 2$ cells with resistin, cell surface area, protein synthesis, and BNP and $\beta$-MHC mRNA expression levels were increased. Subsequent to co-treatment of $\mathrm{H} 9 \mathrm{c} 2$ cells with apelin and resistin, lead to the inhibition of resistin-induced hypertrophic effects by apelin. In addition, treatment with resistin increased phosphorylation of ERK1/2, whereas pretreatment with apelin decreased phosphorylation of ERK1/2, which was increased by resistin. These results indicate that resistin-induced cardiac hypertrophy is inhibited by apelin via inactivation of ERK1/2 cell signaling.
\end{abstract}

Correspondence to: Professor Yong-Zhi Deng, Department of Cardiovascular Surgery, The Affiliated Cardiovascular Hospital of Shanxi Medical University, Shanxi Cardiovascular Hospital (Institute), Taiyuan, Shanxi 030024, P.R. China

E-mail: 13834591065@163.com

Professor Lin Wu, Department of Cardiology, Huaihe Hospital of Henan University, Kaifeng, Henan 475000, P.R. China

E-mail: linwu71ch@yahoo.com

Key words: apelin, resistin, cardiac hypertrophy, extracellular signal-regulated kinase signaling pathway

\section{Introduction}

Cardiac hypertrophy is the response to stress or disease, such as hypertension, myocardial infarction (MI) and valvular heart disease. The incidence of cardiac hypertrophy is $\sim 0.2 \%$ in adults. It is not gender, age, race or geographic specific (1). It causes sudden cardiac death in young patients (2) and develops into heart failure in the elderly. Heart failure may be responsible for as many as $60 \%$ of cardiac hypertrophy-associated deaths. Patients with cardiac hypertrophy are reported to have a mortality rate of $\sim 1.0 \%$ per year (3). The features of cardiac hypertrophy include enlarged cardiomyocyte size, increased protein synthesis, elevated fetal gene atrial natriuretic peptide, brain natriuretic peptide (BNP) and $\beta$-myosin heavy chain $(\beta-\mathrm{MHC})$ expression, and abnormal sarcomeric organization, as well as heightened expression of fibronectin. There are numerous cell signaling pathways associated with cardiac hypertrophy and cardiac failure, including signal transducer and activator of transcription 3, Akt, extracellular signal-regulated kinase (ERK)1/2 and liver kinase B1/5' AMP-activated protein kinase (4-6).

Resistin is an adipocyte-secreted adipokine, which has been linked to obesity, diabetes, insulin resistance and cardiac hypertrophy $(7,8)$. Loss of resistin has been shown to improve insulin sensitivity (9). In addition, treatment with resistin causes glucose intolerance (10). Resistin is regulated by cytokines, including endothelin, insulin, insulin-like growth factors and peroxisome proliferator-activated receptor $\gamma(11,12)$. In rodents, resistin is located within adipocytes, while human resistin is primarily expressed in macrophages and neutrophils (13-15). Human resistin is released in response to inflammatory stimuli (16), and is found at elevated levels in autoimmune disease and sepsis (17). Previous studies have shown that resistin impairs cardiomyocyte glucose handling and induces cardiac hypertrophy $(8,10)$.

Apelin is an endogenous peptide ligand for the $G$ protein-coupled apelin receptor (APJ). Apelin and APJ are expressed in the heart $(18,19)$. Apelin is synthesized as a 77-amino acid peptide processed into various C-terminal fragments, including apelin-36, -19, -17, -13, -12, and [Pyr1]-apelin-13. Apelin-13 is the most stable amongst 
them $(20,21)$. Deficiency of apelin exacerbates MI adverse remodeling and ischemia-reperfusion (I/R) injury (21). Treatment with apelin promotes myocardial angiogenesis and improves cardiac function in post-MI mice (22). Recent studies have shown that apelin ameliorates high fat diet-induced cardiac hypertrophy (23). Although resistin has been reported to induce cardiac hypertrophy, while apelin is reported to inhibit cardiac hypertrophy, it is not known whether apelin inhibits resistin-induced cardiomyocyte hypertrophy via inactivation of the ERK signaling pathway.

The aim of the current study was to investigate the effects of apelin on ERK cell signaling in the inhibition of resistin-induced cardiomyocyte hypertrophy in $\mathrm{H} 9 \mathrm{c} 2$ cells.

\section{Materials and methods}

Reagents. Apelin-13 was obtained from Phoenix Pharmaceuticals, Inc. (Burlingame, CA, USA). Recombinant human resistin was purchased from Peprotech (Rocky Hill, NJ, USA). The H9c2 cells (rat cardiomyoblast cells) were obtained from the American Type Culture Collection (Manassas, VA, USA). Fetal calf serum was purchased from Zhejiang Tianhang Biological Technology (Huzhou, Zhejiang, China), and polyclonal rabbit anti-rat phosphorylated (p)-ERK1/2 antibody (cat. no. 9101S) and polyclonal rabbit anti-rat ERK1/2 antibody (cat. no. 9102S) were purchased from Cell Signaling Technology, Inc. (Danvers, MA, USA). A UNIQ-10 column Trizol kit was obtained from Shanghai Sangon Biotech Co., Ltd. (Shanghai, China). PrimeScript ${ }^{\circledR}$ RT Master Mix Perfect Real Time and SYBR ${ }^{\circledR}$ Premix Ex Taq ${ }^{\mathrm{TM}}$ II were obtained from Biotechnology Co., Ltd. (Tokyo, Japan).

H9c2 cell culture. H9c2 cells were cultured in Dulbecco's modified Eagle's medium containing 10\% fetal bovine serum (Zhejiang Tianhang Biological Technology) with $1 \%$ penicillin and $1 \%$ streptomycin at a temperature of $37^{\circ} \mathrm{C}$. When the cells reached $70-80 \%$ confluence, they were passaged according to a 1:2 proportion and the medium was changed every 2 days. Cells were seeded into a $35-\mathrm{mm}$ dish at a density of $1 \times 10^{5}$. Cells were cultured in serum-free medium (GE Healthcare Life Sciences, Logan, UT, USA) at $37^{\circ} \mathrm{C}$ overnight and pretreated with $100 \mathrm{nM}$ apelin for $2 \mathrm{~h}$, followed by treatment with $50 \mathrm{ng} / \mathrm{ml}$ resistin for 1 or $48 \mathrm{~h}$.

Determination of cell surface area. Briefly, $8 \times 10^{4}$ cells were seeded into a $35-\mathrm{mm}$ dish. Cells were cultured at $37^{\circ} \mathrm{C}$ with serum-free medium for $18 \mathrm{~h}$ and pretreated with $100 \mathrm{nM}$ apelin for $2 \mathrm{~h}$, then treated with $50 \mathrm{ng} / \mathrm{ml}$ resistin for $48 \mathrm{~h}$. The cell surface area was measured using ImageJ version 1.49 software (National Institutes of Health, Bethesda, MD, USA). Using an inverted microscope, five observation fields of cells were selected at random and 10 of the cells in each observation field were selected for measurement of their cell surface areas (24).

Protein synthesis measurement. Briefly, $1 \times 10^{5}$ cells were seeded into a $35-\mathrm{mm}$ dish. Cells were cultured with serum-free medium for $18 \mathrm{~h}$ and pretreated with apelin at $100 \mathrm{nM}$ for $2 \mathrm{~h}$, and treated with resistin for a further $48 \mathrm{~h}$. Cells were digested with $0.25 \%$ trypsin (Beyotime Institute of Biotechnology,
Beijing, China) for $1 \mathrm{~min}$ and counted under an inverted microscope. The cells were collected and lysed with $100 \mu \mathrm{l}$ tissue lysis buffer (CWBio, Beijing, China). Protein concentrations were measured using a bicinchoninic acid (BCA) protein assay kit (Bio-Rad Laboratories, Inc., Hercules, CA, USA) according to the manufacturer's instructions. Cell protein synthesis was expressed as the relative protein content, which was determined by dividing the total protein quantity by the cell number (24).

Reverse transcription-quantitative polymerase chain reaction $R T$-qPCR). Total RNA was extracted from collected cells using the UNIQ-10 column TRIzol kit and digested with DNase I. The RNA concentration was measured with NanoDrop 1000 (Thermo Fisher Scientific, Waltham, MA, USA). RNA ( $1 \mu \mathrm{g})$ was reverse transcribed into cDNA using the PrimeScript ${ }^{\circledR}$ RT Master Mix Perfect Real Time kit. PCR was performed with the SYBR ${ }^{\circledR}$ Premix Ex Taq ${ }^{\mathrm{TM}}$ II kit using an Applied Biosystems ${ }^{\circledR} 7500$ Fast Real-Time PCR System (Thermo Fisher Scientific, Inc.). The cycling conditions for qPCR were as follows: $95^{\circ} \mathrm{C}$ for $30 \mathrm{sec}$, and 40 cycles at $95^{\circ} \mathrm{C}$ for $5 \mathrm{sec}$ followed by $60^{\circ} \mathrm{C}$ for $31 \mathrm{sec}$. $18 \mathrm{~S}$ rRNA gene expression served as a control and qPCR data analysis was performed with the $\Delta \Delta \mathrm{Cq}$ method (25). The BNP, $\beta$-MHC and $18 \mathrm{~S}$ primers were designed and synthesized by Shanghai Sangon Biotech Co., Ltd. and were as follows: Forward, 5'-GGAGCATTGAGTTGGCTCTC-3' and reverse, 5'-CCA GCTCTCCGAAGTGTTTC-3' for BNP; forward, 5'-CACCCG CGAGTACAACCTTC-3' and reverse, 5'-CCCATACCCACC ATCACACC-3' for $\beta$-MHC; forward, 5'-CACCCGCGAGTA CAACCTTC-3' and reverse, 5'-CCCATACCCACCATC ACACC-3' for $18 \mathrm{~S}$.

Western blot analysis. After the cells reached $80-90 \%$ confluence, they were washed twice with $1 \mathrm{X}$ phosphate-buffered saline, digested with $0.25 \%$ trypsin for $1 \mathrm{~min}$ and centrifuged at $1,000 \mathrm{x} \mathrm{g}$ for $5 \mathrm{~min}$ at $4^{\circ} \mathrm{C}$. Cells were added with $100 \mu \mathrm{l}$ lysis buffer (CWBio) and placed in ice for $20 \mathrm{~min}$. The lysates were centrifuged at $10,000 \mathrm{x}$ g for $15 \mathrm{~min}$ at $4^{\circ} \mathrm{C}$ and the supernatant was isolated. The protein concentration was determined by BCA assay and 5X Laemmli's buffer (CWBio) was added to samples. The lysates were heated at $95^{\circ} \mathrm{C}$ for $5 \mathrm{~min}$ and separated by $10 \%$ sodium dodecyl sulfate-polyacrylamide gel electrophoresis. The proteins were transferred onto polyvinylidene fluoride membranes (Merck Millipore, Billerica, MA, USA) at $200 \mathrm{~mA}$ for $30 \mathrm{~min}$, and blocking was performed with Tris-buffered saline and Tween-20 (TBST) buffer $(20 \mathrm{mM}$ Tris- $\mathrm{HCl}, 150 \mathrm{mM} \mathrm{NaCl}$ and $0.1 \%$ Tween-20) containing $5 \%$ non-fat milk for $1 \mathrm{~h}$ at room temperature. The membranes were incubated in TBST buffer containing 5\% non-fat milk with the following primary antibodies: Polyclonal rabbit anti-rat p-ERK $(1: 1,000)$ and polyclonal rabbit anti-rat ERK $(1: 1,000)$ and polyclonal rabbit anti-rat $\beta$-actin (cat. no. 4967S; 1:1,000; Cell Signaling Technology, Inc.) at $4^{\circ} \mathrm{C}$ overnight. After incubation with the primary antibodies, horseradish peroxide-conjugated anti-rabbit secondary antibodies [cat. no. 111-035-003 (polyclonal goat anti-rabbit); 1:10,000; Jackson ImmunoResearch, Inc., West Grove, PA, USA) were incubated at room temperature for $1 \mathrm{~h}$. The blots were visualized with an enhanced chemiluminescence kit (Beijing ComWin Biotech, 
Beijing, China) using a FluorChem ${ }^{\mathrm{TM}} \mathrm{Q}$ Quantitative Western Blot Imaging System (Bio-Techne, Minneapolis, MN, USA). The densitometry of the bands was quantified using NIH ImageJ version 1.49 software.

Statistical analysis. All experiments data were expressed as mean \pm standard deviation and performed at least three times. All statistical analyses were performed by one-way analysis of variance followed by the Bonferroni post hoc test. $\mathrm{P}<0.05$ was considered to indicate a statistically significant difference.

\section{Results}

Apelin inhibits resistin-induced $H 9 c 2$ cell size increase. Resistin treatment was used to induce cardiomyocyte hypertrophy. H9c2 cells were treated with $(50 \mathrm{ng} / \mathrm{ml})$ resistin for $48 \mathrm{~h}$. Resistin significantly increased the cell surface area when compared with the control group $(\mathrm{P}<0.01$; Fig. 1). Pretreatment of cardiomyocytes with $100 \mathrm{nM}$ apelin, significantly decreased the cell surface area that had been increased by resistin compared with the resistin group $(\mathrm{P}<0.01$; Fig. 1$)$.

Apelin decreases resistin-induced cardiomyocyte protein synthesis increase. To analyze whether resistin treatment increases protein synthesis in $\mathrm{H} 9 \mathrm{c} 2$ cells and whether the increase is inhibited by apelin treatment, cultured cardiomyocytes were exposed to resistin in the presence and absence of apelin for $48 \mathrm{~h}$. Resistin significantly increased protein synthesis in cardiomyocyotes compared with the control group $(\mathrm{P}<0.01 ;$ Fig. 2$)$. Apelin treatment decreased the protein synthesis that had been increased by resistin as compared with the resistin group $(\mathrm{P}<0.01 ;$ Fig. 2).

Apelin decreases the resistin-induced increased expression of $B N P$ and $\beta-M H C m R N A$. As BNP and $\beta$-MHC are cardiomyocyte hypertrophy markers, the effect of apelin on expression of BNP and $\beta$-MHC mRNA induced by resistin in H9c2 cells was investigated. Resistin treatment increased the expression of BNP and $\beta$-MHC at the mRNA level compared with the control group $(\mathrm{P}<0.01$; Fig. $3 \mathrm{~A}$ and $\mathrm{B})$. Apelin co-treatment with resistin suppressed resistin-induced increase of BNP and $\beta$-MHC mRNA expression as compared with the resistin group $(\mathrm{P}<0.01$; Fig. $3 \mathrm{~A}$ and $\mathrm{B})$.

Apelin decreases phosphorylation of ERK1/2 that is increased by resistin. To elucidate the underlying molecular mechanism by which apelin inhibits resistin-induced cardiomyocyte hypertrophy, western blot analysis was performed to detect the phosphorylation of ERK1/2 upon apelin and resistin co-treatment. Treatment with resistin decreased phosphorylation of ERK1/2 compared with the control cells $(\mathrm{P}<0.01$; Fig. 4), whereas total ERK1/2 protein expression remained unchanged. By contrast, pretreatment of apelin suppressed expression of $\mathrm{p}$-ERK $1 / 2$ as compared with the resistin group $(\mathrm{P}<0.01$; Fig. 4).

\section{Discussion}

Previous studies have indicated that resistin induces cardiac hypertrophy (8), while apelin inhibits cardiac hypertrophy (23);

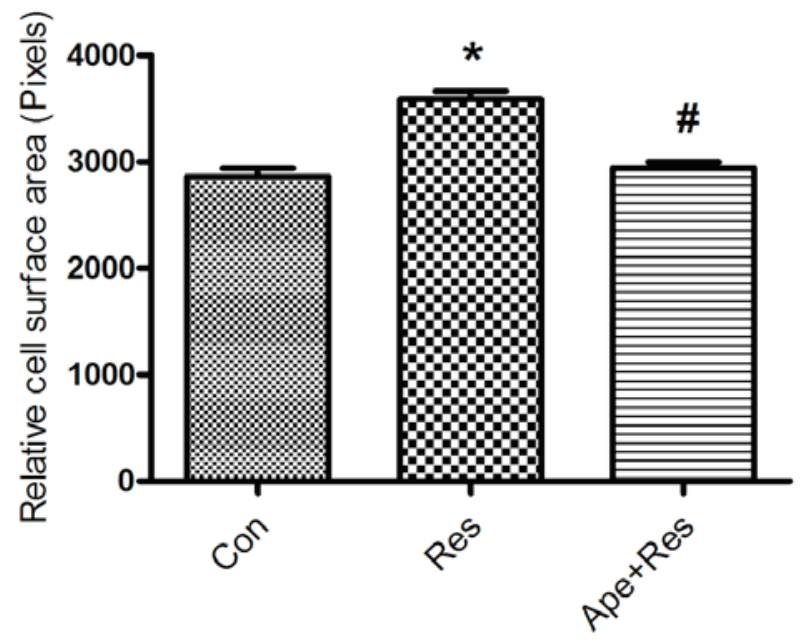

Figure 1. Effects of apelin on cell surface area, which was increased by resistin. Data are presented as the mean \pm standard deviation. ${ }^{*} \mathrm{P}<0.01$ vs. the Con group, ${ }^{\#} \mathrm{P}<0.01$ vs. the Res group. Con, control; Res, resistin; Ape, apelin.

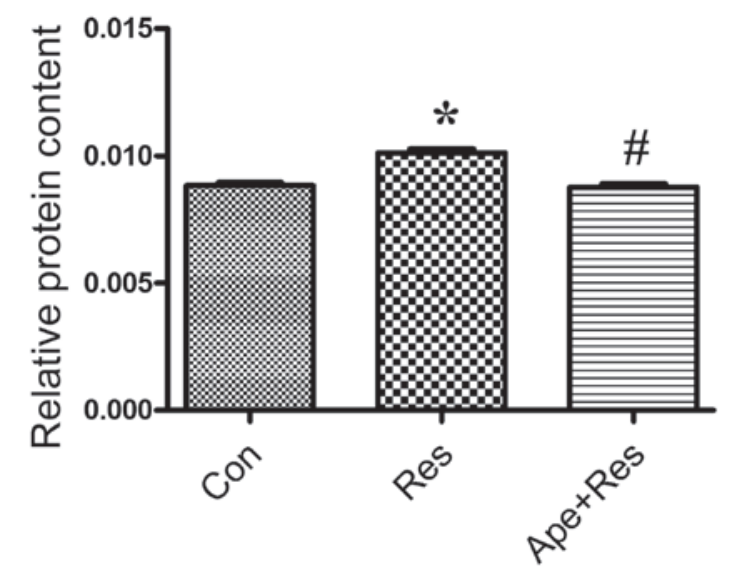

Figure 2. Effects of apelin on protein synthesis, which was increased by resistin. Cell protein contents were measured and normalized to the cell number. Data represent the mean \pm standard deviation. ${ }^{*} \mathrm{P}<0.01$ vs. the Con group, ${ }^{\#} \mathrm{P}<0.01$ vs. the Res group. Con, control; Res, resistin; Ape, apelin.

however, the underlying molecular mechanisms by which apelin inhibits resistin-induced cardiac hypertrophy remain largely unknown. To the best of our knowledge, this is the first study to investigate apelin suppressing resistin-induced cardiomyocyte hypertrophy via the inactivation of the ERK1/2 signaling pathway. In the current study, resistin increased cell size, protein synthesis and the expression of hypertrophic markers, BNP and $\beta$-MHC at the mRNA level, whereas apelin suppressed these effects that were induced by resistin. This indicated that resistin-induced cardiomyocyte hypertrophy may be inhibited by apelin.

Resistin is a secreted adipokine. Resistin function is associated with obesity, diabetes and insulin resistance. Treatment with resistin impairs glucose tolerance and insulin action, whereas loss of resistin function improves insulin resistance $(9,26,27)$ and Resistin promotes endothelial dysfunction and I/R myocardial injury (28-30). Hyperresistinemia may contribute to the impairment of cardiac contractility and diabetic cardiac function (31). Overexpression of resistin in 

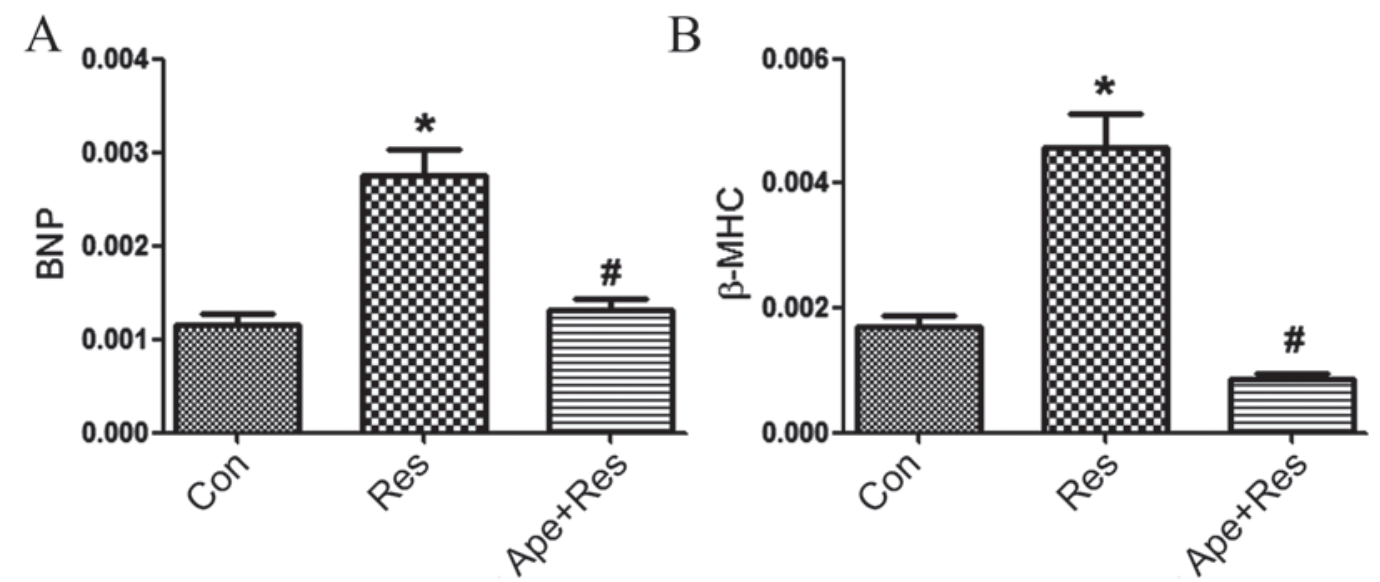

Figure 3. Effects of apelin on the resistin-induced increase of BNP and $\beta$-MHC mRNA expression. (A) BNP and (B) $\beta$-MHC mRNA levels were examined by reverse transcription-quantitative polymerase chain reaction. Data are presented as the mean \pm standard deviation. ${ }^{*} \mathrm{P}<0.01$ vs. the Con group, ${ }^{*} \mathrm{P}<0.01$ vs. the Res group. Con, control; Res, resistin; Ape, apelin.
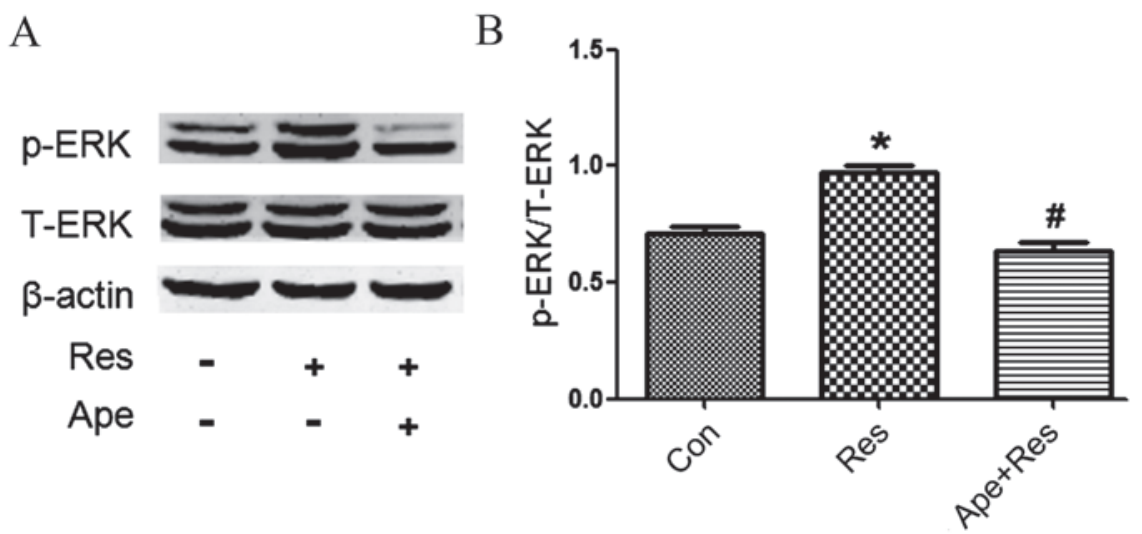

Figure 4. Effects of apelin on the p-ERK1/2 expression, which was increased by resistin. (A) Representive western blot. (B) The expression of p-ERK1/2 was normalized to ERK. Data are presented as the mean \pm standard deviation. ${ }^{*} \mathrm{P}<0.01$ vs. the Con group, ${ }^{\#} \mathrm{P}<0.01$ vs. the Res group. $\mathrm{p}$, phosphorylated; ERK, extracellular regulted kinase; Con, control; Res, resistin; Ape, apelin.

vivo using adeno-associated virus serotype 9 significantly decreases left ventricular contractility and induces oxidative stress, fibrosis, apoptosis and myocardial remodeling in normal rats (32). Furthermore, overexpression of resistin induces cardiac hypertrophy in neonatal rat cardiomyocytes through activation of oxidative stress, insulin receptor substrate 1 (IRS1)/mitogen-activated protein kinase (MAPK) (8), AMPK/mechanistic target of rapamycin/p70S6 kinase and apoptosis signal-regulating kinase $1 / \mathrm{c}$-Jun $\mathrm{N}$-terminal kinases/IRS1 signaling pathways (33). In the current study, $\mathrm{H} 9 \mathrm{c} 2$ cells were used as a model and treated with resistin to induce cardiomyocyte hypertrophy. Treatment with resistin also induced an increase in ERK1/2 phosphorylation, indicating that resistin induces cardiomyocyte hypertrophy via activation of the ERK signaling pathway.

The adipokine, apelin is an endogenous ligand for the G protein-coupled receptor APJ. Apelin and APJ are expressed in the heart. Adipocytes secrete apelin and cardiomyocytes also secrete apelin (34). Human studies have demonstrated that the apelin-AJP system is downregulated in the hypertrophic heart $(35,36)$. Apelin treatment abolishes development of cardiac hypertrophy, as well as preventing fibrosis progression and cardiac contractile dysfunction (37). In addition, apelin gene therapy increases myocardial vascular density and ameliorates diabetic cardiomyopathy via upregulation of sirtuin 3 (38). Previous studies demonstrated that apelin treatment contributes to cardioprotection in cardiac I/R injury, as well as angiotensin II- or isoproterenol-induced cardiac remodeling $(39,40)$. In the absence of apelin, stretch signals through the apelin receptor are mediated via $\beta$-arrestins resulting in detrimental cardiac hypertrophy (41). Notably, apelin knockout mice display impaired cardiac contractility with aging and developed progressive heart failure induced by pressure overload (19). Furthermore, apelin knockout mice and APJ knockout mice showed only modest declines in cardiac function (42). It has been demonstrated that ERK1/2 signaling is necessary for promoting hypertrophic growth. ERK1 and ERK2 are regulated by MAPK kinases (MEK) 1 and MEK2, and ERK1/2 proteins are phosphorylated by MEK1/2 at a threonine and adjacent tyrosine residue. The ERK1/2 signaling pathway has been associated with the development of cardiac hypertrophy and cardiac failure (43). The present study demonstrated that resistin increases phosphorylation of ERK1/2, whereas apelin decreases the phosphorylation of ERK1/2, which was increased by resistin. These results indicate that resistin-induced cardiomyocyte hypertrophy is 
inhibited by apelin via inactivation of the ERK1/2 signaling pathway.

In conclusion, resistin exposure causes increased BNP and $\beta$-MHC mRNA expression levels, greater cell surface area and protein synthesis, as well as increased ERK1/2 phosphorylation, while apelin inhibits these resistin-induced effects. These findings indicate that apelin inhibits resistin-induced cardiomyocyte hypertrophy via inactivation of the ERK1/2 signaling pathway. The present results provide novel insight, presenting apelin as a useful treatment for cardiac hypertrophy.

\section{Acknowledgements}

The present study was supported by the Key Research and Development Program of Shaanxi Province (grant no. 201603D321057) and Basic and Cutting-Edge Technology Research Project of Henan Province (grant no. 142300410118).

\section{References}

1. Maron BJ: Hypertrophic cardiomyopathy: A systematic review. JAMA 287: 1308-1320, 2002.

2. Chugh SS, Reinier K, Teodorescu C, Evanado A, Kehr E, Al Samara M, Mariani R, Gunson K and Jui J: Epidemiology of sudden cardiac death: Clinical and research implications. Prog Cardiovasc Dis 51: 213-228, 2008.

3. Beohar N, Zajarias A, Thourani VH, Herrmann HC, Mack M, Kapadia S, Green P, Arnold SV, Cohen DJ, Généreux P, et al: Analysis of early out-of hospital mortality after transcatheter aortic valve implantation among patients with aortic stenosis successfully discharged from the hospital and alive at 30 days (from the placement of aortic transcatheter valves trial). Am J Cardiol 114: 1550-1555, 2014.

4. Tham YK, Bernardo BC, Ooi JY, Weeks KL and McMullen JR: Pathophysiology of cardiac hypertrophy and heart failure: Signaling pathways and novel therapeutic targets. Arch Toxicol 89: 1401-1438, 2015.

5. Jeong K, Kwon H, Min C and Pak Y: Modulation of the caveolin-3 localization to caveolae and STAT3 to mitochondria by catecholamine-induced cardiac hypertrophy in H9c2 cardiomyoblasts. Exp Mol Med 41: 226-235, 2009.

6. Lee H, Yoo YS, Lee D and Song EJ: Cholesterol induces cardiac hypertrophy by activating the AKT pathway. J Steroid Biochem Mol Biol 138: 307-313, 2013.

7. Steppan CM, Bailey ST, Bhat S, Brown EJ, Banerjee RR, Wright CM, Patel HR, Ahima RS and Lazar MA: The hormone resistin links obesity to diabetes. Nature 409: 307-312, 2001.

8. Kim M, Oh JK, Sakata S, Liang I, Park W, Hajjar RJ and Lebeche D: Role of resistin in cardiac contractility and hypertrophy. J Mol Cell Cardiol 45: 270-280, 2008.

9. Muse ED, Obici S, Bhanot S, Monia BP, McKay RA, Rajala MW, Scherer PE and Rossetti L: Role of resistin in diet-induced hepatic insulin resistance. J Clin Invest 114: 232-239, 2004.

10. Graveleau C, Zaha VG, Mohajer A, Banerjee RR, Dudley-Rucker N, Steppan CM, Rajala MW, Scherer PE, Ahima RS, Lazar MA, et al: Mouse and human resistins impair glucose transport in primary mouse cardiomyocytes, and oligomerization is required for this biological action. J Biol Chem 280: 31679-31685, 2005.

11. Chen YH, Hung PF and Kao YH: IGF-I downregulates resistin gene expression and protein secretion. Am J Physiol Endocrinol Metab 288: E1019-E1027, 2005.

12. Patel L, Buckels AC, Kinghorn IJ, Murdock PR, Holbrook JD, Plumpton C, Macphee $\mathrm{CH}$ and Smith SA: Resistin is expressed in human macrophages and directly regulated by PPAR gamma activators. Biochem Biophys Res Commun 300: 472-476, 2003.

13. Steppan CM and Lazar MA: The current biology of resistin. J Intern Med 255: 439-447, 2004.

14. Pang SS and Le YY: Role of resistin in inflammation and inflammation-related diseases. Cell Mol Immunol 3: 29-34, 2006.

15. Bokarewa M, Nagaev I, Dahlberg L, Smith U and Tarkowski A: Resistin, an adipokine with potent proinflammatory properties. J Immunol 174: 5789-5795, 2005.
16. Kunnari AM, Savolainen ER, Ukkola OH, Kesäniemi YA and Jokela MA: The expression of human resistin in different leucocyte lineages is modulated by LPS and TNFalpha. Regul Pept 157: 57-63, 2009.

17. Schwartz DR and Lazar MA: Human resistin: Found in translation from mouse to man. Trends Endocrinol Metab 22: 259-265, 2011.

18. Szokodi I, Tavi P, Földes G, Voutilainen-Myllylä S, Ilves M, Tokola H, Pikkarainen S, Piuhola J, Rysä J, Tóth M, et al: Apelin, the novel endogenous ligand of the orphan receptor APJ, regulates cardiac contractility. Circ Res 91: 434-440, 2002.

19. Kuba K, Zhang L, Imai Y, Arab S, Chen M, Maekawa Y, Leschnik M, Leibbrandt A, Markovic M, Schwaighofer J, et al: Impaired heart contractility in Apelin gene-deficient mice associated with aging and pressure overload. Circ Res 101: e32-e42, 2007.

20. Maguire JJ, Kleinz MJ, Pitkin SL and Davenport AP: [Pyr1] apelin-13 identified as the predominant apelin isoform in the human heart: Vasoactive mechanisms and inotropic action in disease. Hypertension 54: 598-604, 2009.

21. Wang W, McKinnie SM, Patel VB, Haddad G, Wang Z, Zhabyeyev P, Das SK, Basu R, McLean B, Kandalam V, et al: Loss of Apelin exacerbates myocardial infarction adverse remodeling and ischemia-reperfusion injury: Therapeutic potential of synthetic Apelin analogues. J Am Heart Assoc 2: e000249, 2013.

22. Li L, Zeng H and Chen JX: Apelin-13 increases myocardial progenitor cells and improves repair postmyocardial infarction. Am J Physiol Heart Circ Physiol 303: H605-H618, 2012.

23. Ceylan-Isik AF, Kandadi MR, Xu X, Hua Y, Chicco AJ, Ren J and Nair S: Apelin administration ameliorates high fat diet-induced cardiac hypertrophy and contractile dysfunction. J Mol Cell Cardiol 63: 4-13, 2013.

24. Liu P, Cheng GC, Ye QH, Deng YZ and Wu L: LKB1/AMPK pathway mediates resistin-induced cardiomyocyte hypertrophy in H9c2 embryonic rat cardiomyocytes. Biomed Rep 4: 387-391, 2016.

25. Livak KJ and Schmittgen TD: Analysis of relative gene expression data using real-time quantitative PCR and the 2(-Delta Delta C(T)) Method. Methods 25: 402-408, 2001

26. Banerjee RR, Rangwala SM, Shapiro JS, Rich AS, Rhoades B, Qi Y, Wang J, Rajala MW, Pocai A, Scherer PE, et al: Regulation of fasted blood glucose by resistin. Science 303: 1195-1198, 2004.

27. Rajala MW, Obici S, Scherer PE and Rossetti L: Adipose-derived resistin and gut-derived resistin-like molecule-beta selectively impair insulin action on glucose production. J Clin Invest 111: 225-230, 2003.

28. Gao J, Chang Chua C, Chen Z, Wang H, Xu X, C Hamdy R, McMullen JR, Shioi T, Izumo S and Chua BH: Resistin, an adipocytokine, offers protection against acute myocardial infarction. J Mol Cell Cardiol 43: 601-609, 2007.

29. Gualillo O, González-Juanatey JR and Lago F: The emerging role of adipokines as mediators of cardiovascular function: Physiologic and clinical perspectives. Trends Cardiovasc Med 17: 275-283, 2007.

30. Rothwell SE, Richards AM and Pemberton CJ: Resistin worsens cardiac ischaemia-reperfusion injury. Biochem Biophys Res Commun 349: 400-407, 2006.

31. Bobbert P, Jenke A, Bobbert T, Kühl U, Rauch U, Lassner D, Scheibenbogen C, Poller W, Schultheiss HP and Skurk C: High leptin and resistin expression in chronic heart failure: Adverse outcome in patients with dilated and inflammatory cardiomyopathy. Eur J Heart Fail 14: 1265-1275, 2012.

32. Chemaly ER, Hadri L, Zhang S, Kim M, Kohlbrenner E, Sheng J, Liang L, Chen J, K-Raman P, Hajjar RJ, et al: Long-term in vivo resistin overexpression induces myocardial dysfunction and remodeling in rats. J Mol Cell Cardiol 51: 144-155, 2011.

33. Kang S, Chemaly ER, Hajjar RJ and Lebeche D: Resistin promotes cardiac hypertrophy via the AMP-activated protein kinase/mammalian target of rapamycin (AMPK/mTOR) and c-Jun N-terminal kinase/insulin receptor substrate 1 (JNK/IRS1) pathways. J Biol Chem 286: 18465-18473, 2011.

34. Kageyama K, Hanada K and Suda T: Regulation of corticotropin-releasing factor receptor type 2beta mRNA by mitogen-activated protein kinases in aortic smooth muscle cells. Regul Pept 126: 223-231, 2005.

35. Iwanaga Y, Kihara Y, Takenaka $\mathrm{H}$ and Kita T: Down-regulation of cardiac apelin system in hypertrophied and failing hearts: Possible role of angiotensin II-angiotensin type 1 receptor system. J Mol Cell Cardiol 41: 798-806, 2006. 
36. Földes G, Horkay F, Szokodi I, Vuolteenaho O, Ilves M, Lindstedt KA, Mäyränpää M, Sármán B, Seres L, Skoumal R, et al: Circulating and cardiac levels of apelin, the novel ligand of the orphan receptor APJ, in patients with heart failure. Biochem Biophys Res Commun 308: 480-485, 2003.

37. Pchejetski D, Foussal C, Alfarano C, Lairez O, Calise D, Guilbeau-Frugier C, Schaak S, Seguelas MH, Wanecq E, Valet $\mathrm{P}$, et al: Apelin prevents cardiac fibroblast activation and collagen production through inhibition of sphingosine kinase 1. Eur Heart J 33: 2360-2369, 2012.

38. Zeng H, He X, Hou X, Li L and Chen JX: Apelin gene therapy increases myocardial vascular density and ameliorates diabetic cardiomyopathy via upregulation of sirtuin 3. Am J Physiol Heart Circ Physiol 306: H585-H597, 2014

39. Jia YX, Pan CS, Zhang J, Geng B, Zhao J, Gerns H, Yang J, Chang JK, Tang CS and Qi YF: Apelin protects myocardial injury induced by isoproterenol in rats. Regul Pept 133: 147-154, 2006.
40. Siddiquee K, Hampton J, Khan S, Zadory D, Gleaves L, Vaughan DE and Smith LH: Apelin protects against angiotensin II-induced cardiovascular fibrosis and decreases plasminogen activator inhibitor type-1 production. J Hypertens 29: 724-731, 2011.

41. Scimia MC, Hurtado C, Ray S, Metzler S, Wei K, Wang J, Woods CE, Purcell NH, Catalucci D, Akasaka T, et al: APJ acts as a dual receptor in cardiac hypertrophy. Nature 488: 394-398, 2012.

42. Charo DN, Ho M, Fajardo G, Kawana M, Kundu RK, Sheikh AY, Finsterbach TP, Leeper NJ, Ernst KV, Chen MM, et al: Endogenous regulation of cardiovascular function by apelin-APJ. Am J Physiol Heart Circ Physiol 297: H1904-H1913, 2009.

43. Mutlak M and Kehat I: Extracellular signal-regulated kinases 1/2 as regulators of cardiac hypertrophy. Front Pharmacol 6: 149, 2015. 